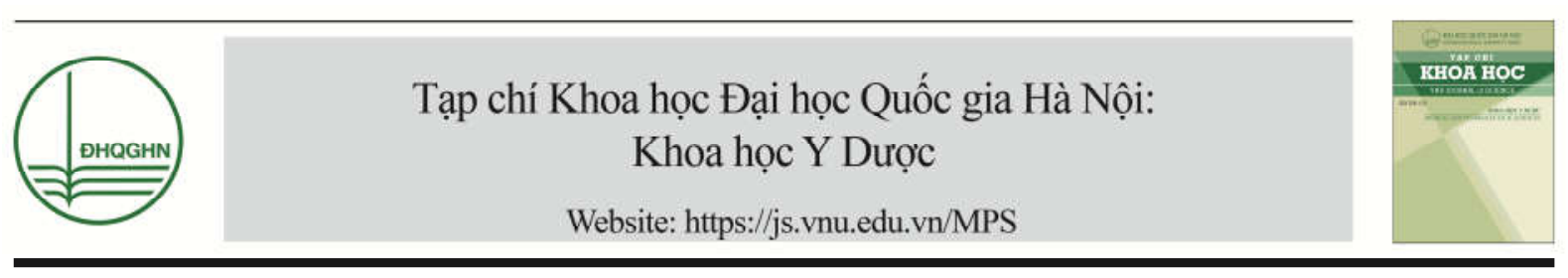

\title{
Xây dựng quy trình phân tích đa hình rs11212617 liên quan đến đáp ứng điều trị Metformin ở bệnh nhân Đái tháo đường type 2
}

\author{
Nguyễn Thị Thúy Mậu ${ }^{1, *}$, Phạm Thị Quân², Phạm Thị Hồng Nhung ${ }^{1}$, \\ Đỗ Thị Lệ Hằng ${ }^{1}$, Phí Thị Tú Anh ${ }^{1}$, Vũ Thị Thơm ${ }^{1}$ \\ ${ }^{1}$ Khoa Y dược, Đại học Quốc gia Hà Nội, 144 Xuân Thủy, Cầu Giấy, Hà Nội, Việt Nam \\ ${ }^{2}$ Đại học Y Hà Nội, 01 Tôn Thất Tùng, Đống Đa, Hà Nội, Việt Nam
}

Nhận ngày 02 tháng 4 năm 2018

Chỉnh sửa ngày 01 tháng 5 năm 2018; Chấp nhận đăng ngày 12 tháng 6 năm 2018

\begin{abstract}
Tóm tắt: Metformin hiện nay được khuyến cáo là thuốc sử dụng đầu tay trong điều trị tình trạng tăng đường huyết ở bệnh nhân Đái tháo đường type 2 . Tuy nhiên, hiệu quả điều trị của mỗi bệnh nhân là khác nhau. Nghiên cứu gần đây cho thấy biến đổi liên quan đến gen ATM có ảnh hưởng đến đáp ứng hạ đường huyết của thuốc. Trong đó có đa hình di truyền ở SNP rs11212617 (C>A), nằm trên cánh dài NST số 11 , với alen $\mathrm{C}$ có liên quan đến đáp ứng lâm sàng tốt hơn so với alen $\mathrm{A}$. Vì vậy, chúng tôi tiến hành xây dựng quy trình phân tích đa hình di truyền rs11212617 trên nhóm bệnh nhân Đái tháo đường type 2 . Các mẫu máu đã tách chiết DNA, phương pháp PCR và giải trình tự Sanger được sử dụng để xác định đa hình di truyền rs11212617 của 22 bệnh nhân người Việt Nam. Kết quả nghiên cứu cho thấy chúng tôi đã hoàn thiện được quy trình phân tích đa hình di truyền rs11212617. Tổng số có 22 bệnh nhân được xác định kiểu gen: $54,5 \%$ có kiểu gen $\mathrm{CC}$, $31,8 \%$ có kiểu gen $\mathrm{CA}$ và $13,7 \%$ có kiểu gen $\mathrm{AA}$. Tần số xuất hiện alen $\mathrm{C}$ là 0,71 , alen $\mathrm{A}$ là 0,29 . Từ kết quả này sẽ giúp phát triển các nghiên cứu tiếp theo nhằm đánh giá mức độ đáp ứng lâm sàng của kiểu gen với điều trị thuốc trên quần thể người Việt $\mathrm{Nam}$, từ đó nâng cao hiệu quả điều trị bệnh.
\end{abstract}

Tì khóa: rs11212617, đa hình di truyền, Metformin, đái tháo đường type 2.

\section{1. Đặt vấn đề}

Đái tháo đường (ĐTĐ) type 2 là một bệnh rối loạn chuyển hóa đang ngày càng gia tăng trên toàn thế giới, đặc biệt ở các nước đang phát triển [1]. Tại Việt Nam, từ năm 2002 đến năm

\footnotetext{
* Tác giả liên hệ. ĐT.: 84-986100137.

Email: thuymauhmu@gmail.com

https://doi.org/10.25073/2588-1132/vnumps.4105
}

2012, tỷ lệ mắc bệnh ĐTĐ đã tăng gấp đôi từ $2,7 \%$ lên $5,4 \%$, và theo ước tính vào năm 2030 sẽ có tới 3,42 triệu người mắc phải căn bệnh này [2]. Đặc điểm chính của bệnh là nồng độ glucose máu tăng cao, lâu dài sẽ gây tổn thương nhiều cơ quan trong cơ thể, tăng nguy cơ biến chứng tim mạch, thận, thần kinh và nhiều bệnh lý khác [3]. Dự phòng và điều trị ĐTĐ đang trở thành một trong những vấn đề chính trong công tác chăm sóc sức khỏe cộng đồng. Metformin, 
một dẫn xuất của Biguanide, hiện được khuyến cáo sử dụng phổ biến đề điều trị tình trạng tăng đường huyết của bệnh nhân ĐTĐ type 2 , trong cả đơn trị liệu và trị liệu kết hợp (theo phác đồ của Hiệp hội Đái tháo đường Hoa Kỳ) [4].

Theo ADA 2017, một trong các tiêu chuẩn chẩn đoán ĐTĐ là khi bệnh nhân có $\mathrm{HbAlc} \geq$ $6,5 \%$ và mục đích điều trị là duy trì chỉ số này $\leq$ $7 \%$ [4]. Tuy nhiên không phải tất cả bệnh nhân ĐTĐ type 2 đều đáp ứng tốt với điều trị Metformin. Hơn một phần ba bệnh nhân ĐTĐ type 2 không đáp ứng với liều thông thường được khuyến cáo [5]. Nghiên cứu gần đây cho thấy gen ataxia telangiecsia mutated (ATM) có vai trò điều hòa tác động của Metformin thông qua hoạt hóa AMP-activated protein kinase (AMPK), và các biến đổi trong gen này sẽ ảnh hưởng đến đáp ứng hạ đường huyết của thuốc. Trong đó có đa hình di truyền ở SNP rs11212617, đột biến thay $\mathrm{C}$ thành $\mathrm{A}$ ở vị trí 108412434 trên cánh dài nhiễm sắc thể (NST) số 11 . Nghiên cứu cho thấy bệnh nhân mang kiểu gen AA có đáp ứng giảm đường huyết khi sử dụng Metformin thấp hơn so với bệnh nhân có kiểu gen $\mathrm{CC}[6,7]$. Do đó, việc xác định kiểu SNP này có vai trò quan trọng trong tiên lượng đáp ứng thuốc điều trị ở từng bệnh nhân. Ở Việt Nam hiện chưa có đề tài nào xây dựng quy trình phân tích SNP này. Do đó, với mục đích đưa xét nghiệm xác định kiểu gen cho bệnh nhân như một xét nghiệm thường quy tại các cơ sở khám chữa bệnh, chúng tôi tiến hành thực hiện đề tài: "Xây dựng quy trình phân tích đa hình rs11212617 liên quan đến đáp ứng điều trị Metformin ở bệnh nhân đái tháo đường type 2" với hai mục tiêu: (1) Tối ưu hóa quy trình xác định đa hình di truyền rs11212617 trên bệnh nhân ĐTĐ type 2, và (2) Áp dụng quy trình để xác định đa hình di truyền rs11212617 trên một số bệnh nhân ĐTĐ type 2 .

\section{2. Đối tượng và phương pháp nghiên cứu}

Nghiên cứu được tiến hành theo phương pháp mô tả cắt ngang, sử dụng phương pháp chọn mẫu thuận tiện. 22 bệnh nhân được chẩn đoán ĐTĐ type 2 theo tiêu chuẩn ADA 2017 được điều trị bằng Metformin tại Bệnh viện Dệt May, Hà Nội. Thời gian lấy mẫu từ 6/2017đến 03/2018. Nghiên cứu tuân thủ theo quy định và được thông qua bởi Hội đồng đạo đức của Khoa Y Dược, ĐHQG Hà Nội.

Thu thập và bảo quản mẫu máu: 22 mẫu máu của bệnh nhân mắc ĐTĐ type 2 thu thập tại Bệnh viện Dệt May, được bảo quản trong EDTA lưu ở $-20^{\circ} \mathrm{C}$ cho đến khi sử dụng. Ống máu được ghi đầy đủ thông tin: tên bệnh nhân, tuổi, mã bệnh án.

Tách chiết DNA tổng số: DNA tổng số được tách từ mẫu máu, sử dụng E.Z.N.A blood DNA Mini Kit (Omega-Biotek) theo quy trình khuyến cáo của hãng.

Nhân dòng phân đoạn mang SNP rs11212617: Để có quy trình nhân dòng đặc hiệu và ổn định, chúng tôi xác định nhiệt độ gắn mồi, nồng độ hoạt động tối ưu của các thành phần trong phản ứng PCR sử dụng DreamTaq DNA Polymerase (Thermo Scientific). Khoảng nhiệt độ gắn mồi khảo sát từ $55-70{ }^{\circ} \mathrm{C}$, khoảng nồng độ mồi từ $0,1-0,9 \mu \mathrm{M}$, khoảng nồng độ DNA từ 5-200 ng/ $\mu 1$. Sản phẩm PCR được điện di trên gel agarose $1,5 \%$, cùng thang chuẩn Ruler 100 bp Plus DNA Ladder (SM0321, Thermo Scientific).

Trình tự mồi nhân dòng trong phản ứng PCR: mồi xuôi ATM-F: 5" TGGGTTGCTTGTGGATAACATATAGTT GG 3' và mồi ngược ATM-R: 5' GAGAAGGCAGTAAAGTGAAGGAATAC AGAG 3'[8]. Đoạn DNA nhân lên có độ dài $209 \mathrm{bp}$.

Xác định kiểu gen bằng phương pháp giải trình tụ: $20 \mu 1$ sản phẩm PCR được gửi giải trình tự tại hãng IDT (Malaysia). Kết quả giải trình tự được đọc bằng phần mềm BioEdit version 7.2.6 để xác định kiểu gen của mỗi bệnh nhân. Tần số các alen sẽ được tính toán và so sánh với tần số lý thuyết theo định luật Hardy-Weinberg sử dụng Chi-square test. 


\section{Kết quả nghiên cứu}

Tách chiết DNA tổng số: $2 \mathrm{ml}$ máu tĩnh mạch của mỗi bệnh nhân được chống đông bằng EDTA đều tách được DNA tổng số bằng E.Z.N.A blood DNA Mini Kit. Nồng độ DNA thu hồi sau tách chiết dao động từ 13,85 - 141,8

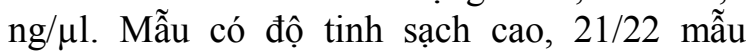
$(95,5 \%)$ có chỉ số $A_{260} / A_{280}$ dao động trong khoảng $1,7-2,0$, chứng tỏ DNA được tách chiết đạt yêu cầu cho phản ứng khuếch đại DNA bằng $\mathrm{PCR}$.

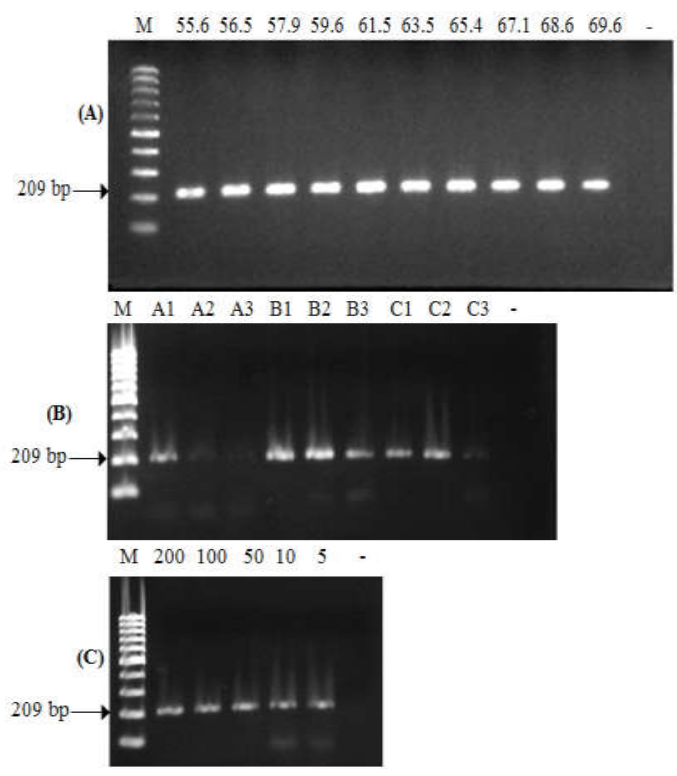

Hình 1. Ảnh điện di trên gel agarose $1,5 \%$ của thí nghiệm tối ưu PCR nhân dòng đoạn DNA chứa SNP rs11212617. A: Tối ưu nhiệt độ gắn mồi. $\mathrm{B}$ : Tối ưu nồng độ mồi. $\mathrm{C}$ : Tối ưu nồng độ DNA trong mẫu máu. Trong hình $(\mathrm{B})$ : $\mathrm{A}$ : nồng độ mồi $0,9 \mu \mathrm{M}$. B: nồng độ mồi $0,3 \mu \mathrm{M}$. C: nồng độ mồi $0,1 \mu \mathrm{M}$. Sử dụng 3 mẫu có nồng độ DNA là 1 : nồng độ DNA $100 \mathrm{ng} / \mu \mathrm{l}$. 2: nồng độ DNA $50 \mathrm{ng} / \mu \mathrm{l}$. 3: nồng độ DNA 10 ng/ $\mu$ l. M: marker GeneRuler TM 100 bp

DNA Ladder. (-): Đối chứng âm.

Nhân dòng phân đoạn mang SNP rs11212617: Kết quả điện di sản phẩm tối ưu từng thành phần được trình bày ở hình 1 . Dựa trên kết quả hình ảnh băng điện di lên sáng rõ, không có băng phụ, chúng tôi lựa chọn nhiệt độ gắn mồi tối ưu là $61,5^{\circ} \mathrm{C}$, nồng độ mồi tối ưu ở $0,3 \mu \mathrm{M}$. Về nồng độ DNA, chúng tôi lựa chọn trong khoảng từ $5-200 \mathrm{ng} / \mu \mathrm{l}$, vì ở tất cả các vị trí băng điện di đều lên rõ, không có băng phụ,chứng tỏ phương pháp có độ nhạy, có thể nhân dòng đoạn gen với nồng độ DNA rất thấp. Như vậy, chu trình nhiệt cho phản ứng $\mathrm{PCR}$ gồm 3 giai đoạn: biến tính ban đầu $95^{\circ} \mathrm{C}$ trong 3 phút; 35 chu kỳ: $95^{\circ} \mathrm{C}$ trong 30 giây, gắn mồi ở $61,5^{\circ} \mathrm{C}$ trong 30 giây, $72^{\circ} \mathrm{C}$ trong 1 phút; thời gian kéo dài cuối $72^{\circ} \mathrm{C}$ trong 5 phút. Chúng tôi tiến hành kiểm chứng quy trình trên 6 mẫu bệnh nhân và cho kết quả ở hình 2 .

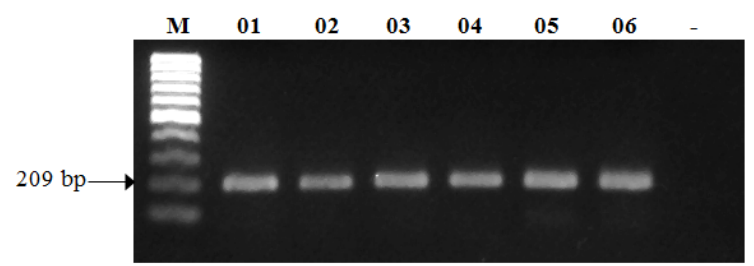

Hình 2. Ảnh điện di trên gel agarose $1,5 \%$ của thí nghiệm tối ưu PCR, sử dụng quy trình tối ưu chạy với 6 mẫu bệnh nhân. M: marker GeneRuler TM 100 bp DNA Ladder. (-): Đối chứng âm.

(A)

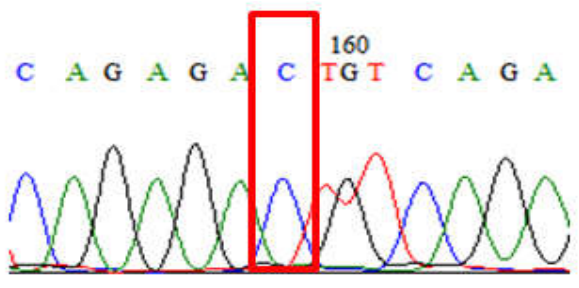

(B)

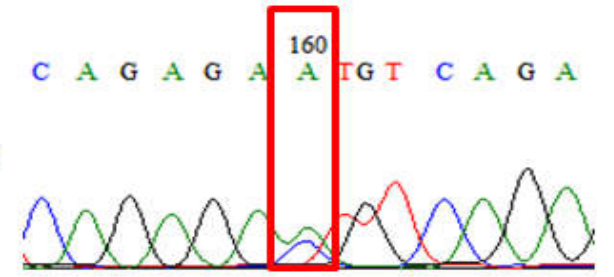

(C)

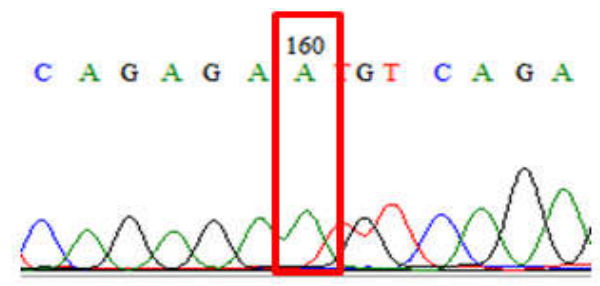

Hình 3. Kết quả giải trình tự đoạn DNA chứa rs11212617. A: kiểu gen CC. B: Kiểu gen CA. C: Kiểu gen AA. Phần đóng khung là vị trí SNP. 
Giải trình tự xác định kiểu gen của bệnh nhân: Dựa vào kết quả giải trình tự mẫu PCR đã tinh sạch, chúng tôi xác định được các kiểu gen đồng hợp $\mathrm{CC}, \mathrm{AA}$ và dị hợp CA. (Hình 3 ). Chúng tôi chia 22 bệnh nhân thành 3 nhóm kiểu gen, với số lượng mỗi nhóm được trình bảy ở bảng 1.Vị trí SNP trên gen: nucleotid thứ 55 tính từ mồi $F$. Trình tự SNP: CCAATTACAAAGGGCAGATCAGAGA[A/ C]TGTCAGAGCGGATAAAAAATCAAGA.

Bảng 1. Đa hình di truyền SNP rs11212617 ở 22 mẫu bệnh nhân nghiên cứu

\begin{tabular}{lll}
\hline $\begin{array}{l}\text { Kiểu gen } \\
\text { rs11212617 }\end{array}$ & Số bệnh nhân & Tỷ lệ \% \\
\hline CC & 12 & $54,5 \%$ \\
CA & 7 & $31,8 \%$ \\
AA & 3 & $13,7 \%$ \\
\hline
\end{tabular}

Tần số của alen $\mathrm{C}$ là 0,71 , alen $\mathrm{A}$ là 0,29 . Kiểm định với Chi-square test, ta có $\chi 2=1,22$ và $p$-value $=0,269$. Như vậy, tần số các alen thu được trong nghiên cứu này phù hợp theo định luật Hardy-Weinberg. Điều đó cũng cho thấy cấu trúc di truyền của các alen này ở người Việt Nam có thể đã trở nên ổn định (ít nhất quần thể 22 bệnh nhân thuộc nghiên cứu này đã có tính đại diện).

\section{Bàn luận}

Kết quả nghiên cứu cho thấy quy trình phân tích xác định được kiểu gen SNP rs11212617 của chúng tôi đã ổn định. Về tách chiết DNA từ mẫu máu toàn phần, một số mẫu có nồng độ DNA thu được khá thấp so với các mẫu còn lại (mẫu nhỏ nhất có nồng độ thu được là 13,85 $\mathrm{ng} / \mu 1)$. Tuy nhiên nồng độ DNA cho lên băng kích thước rõ nằm trong khoảng từ $5-200$ ng/ $\mu$ l, chứng tỏ phương pháp có độ nhạy, với độ tinh sạch OD trong khoảng 1,7 đến 2,0 đạt yêu cầu cho việc thực hiện phản ứng PCR về sau. Quy trình phân tích gen đã tối ưu bao gồm: nhiệt độ gắn mồi ở $61,5^{\circ} \mathrm{C}$, nồng độ mồi là 0,3 $\mu \mathrm{M}$ mỗi mồi, nồng độ DNA trong khoảng 5 $200 \mathrm{ng} / \mu \mathrm{l}$, kết quả này đảm bảo hiệu suất phản ứng cao (băng điện di lên rõ nét, không xuất hiện băng phụ) và tính đạo đức của nghiên cứu.

Nghiên cứu của chúng tôi thực hiện trên 22 bệnh nhân. Với tập hợp mẫu nhỏ nhưng kiểm định Chi-square cho thấy tần số của các alen đã phân bố theo định luật Hardy-Weinberg, nhóm mẫu nghiên cứu có tính đại diện cho quần thể bệnh nhân ĐTĐ type 2 tại khoa Nội, Bệnh viện Dệt May. Phân bố alen trong quần thể người Việt Nam có sự khác biệt với một số quần thể trong các nghiên cứu khác trên thế giới. Nhóm nghiên cứu GoDARTS năm 2011 trên quần thể người châu Âu thực hiện trên 1783 người ở Scotland và 1113 người ở trong thử nghiệm lâm sàng của UKPDS cho thấy alen $\mathrm{C}$ có tỷ lệ thấp hơn (44\%) so với alen $\mathrm{A}$ [7]. Nghiên cứu này cũng cho thấy alen $\mathrm{C}$ có tỷ lệ đáp ứng tốt hơn với Metformin trong việc đạt mục tiêu HbAlc dưới $7 \%\left(\mathrm{OR}=1,64, \mathrm{CI} 1,37-1,99, \mathrm{p}=1,9 * 10^{-7}\right)$. Một nghiên cứu khác tại Mỹ năm 2012 đã tiến hành thử nghiệm lại đáp ứng với Metformin trong một thử nghiệm lâm sàng với 5 nhóm chủng tộc có nguy cơ cao mắc ĐTĐ type 2 và đang điều trị bằng phương pháp thay đổi lối sống hoặc Metformin [9]. Kết quả cho thấy alen $C$ có tần số xuất hiện khác nhau ở các chủng tộc. Cụ thể là alen $\mathrm{C}$ chiếm $42,4 \%$ ở người da trắng, $72,4 \%$ ở người Mỹ gốc Phi, 40,1\% ở người gốc Latinh, $51,6 \%$ ở người gốc Á và $41,5 \%$ ở người gốc Ấn Độ. Tuy nhiên kết quả về đáp ứng điều trị của nghiên cứu này lại không ủng hộ mối liên quan của alen này với việc đáp ứng kiểm soát glucose máu của Metformin. Nghiên cứu mới đây vào năm 2014 của Zhou và cộng sự tiến hành trên quần thể người Hán tại Thượng Hải, Trung Quốc với 359 bệnh nhân mắc ĐTĐ type 2 [10]. Kết quả nghiên cứu này cho thấy alen $\mathrm{C}$ chiếm $67,5 \%$ trong khi alen $\mathrm{A}$ chiếm $32,5 \%$. Tần số phân bố của 3 kiểu gen lần lượt là $44,5 \% \mathrm{CC}, 46 \% \mathrm{CA}$ và $9,5 \% \mathrm{AA}$. Kết quả này tương tự với một nghiên cứu trước với quần thể người Hán tại Bắc Kinh [10]. Các kết quả này gần tương tự với kết quả nghiên cứu của chúng tôi nhất, cho thấy có sự tương đồng về phân bố alen và tần số kiểu gen trong nhóm quần thể người châu Á, khác với các nghiên cứu ở trên thực hiện trên nhóm quần thể Châu Âu và Châu 
Mỹ. Tuy nghiên cứu của chúng tôi thực hiện với cỡ mẫu còn hạn chế, nhưng đã đưa ra kết quả bước đầu khá tin cậy, từ đó có thể giúp định hướng cho các nghiên cứu với cỡ mẫu lớn hơn trong tương lai. Hiện nay, tại Việt Nam, liều dùng Metformin đang dao động trong khoảng 500-2000 mg/ngày. Tuy nhiên với liều cao, tác dụng giảm đường huyết không tăng nhiều, song tác dụng phụ sẽ nhiều hơn. Việc sử dụng thuốc cần thận trọng trong các trường hợp suy thận, bệnh nhân trên 80 tuổi [11]. Vì vậy, trong điều trị bệnh lý ĐTĐ type 2 , việc xác định mức độ đáp ứng điều trị theo kiểu gen sẽ phục vụ tốt hơn trong thực tế lâm sàng, định hướng cho các bác sĩ đưa ra phác đồ điều trị phù hợp trên từng bệnh nhân. Tuy nhiên, để đánh giá rõ hơn vai trò của rs11212617 trong quần thể người Việt Nam, chúng tôi khuyến nghị mở rộng thực hiện các nghiên cứu tiếp theo đánh giá mối liên quan giữa các đa hình di truyền này với đáp ứng điều trị thuốc.

Ngoài ra, một vài hướng nghiên cứu khác mở ra với đa hình di truyền này, như mối liên quan giữa gen $A T M$ và $\mathrm{SNP}$ rs11212617 với bệnh lý tim mạch, đặc biệt là bệnh lý động mạch vành [12]. Đây là một trong những biến chứng thường gặp của bệnh ĐTĐ type 2 , và trong một số trường hợp, điều trị kiểm soát đường huyết đơn thuần tỏ ra chưa hiệu quả trong việc làm giảm tỷ lệ mắc cũng như tử vong do biến chứng này gây ra. Nghiên cứu của Schiekofer và cộng sự năm 2014 thực hiện phân tích kiểu gen rs11212617 trên 240 bệnh nhân nam mắc bệnh lý động mạch vành [13]. Kết quả cho thấy alen A có liên quan đến bệnh lý động mạch vành, cụ thể là gia tăng gần gấp đôi số điểm nguy cơ cũng như số điểm tổn thương theo thang điểm Score và Gensini so với alen $\mathrm{C}$ (cả hai đều có $\mathrm{p}<0,05$ ). Một nghiên cứu khác có nhóm chứng của Ding và cộng sự tiến hành trên quần thể người Hán tại Trung Quốc cũng cho thấy một đa hình di truyền khác thuộc gen $A T M$ (rs $189037 \mathrm{C}>\mathrm{T}$ ) cũng liên quan đến tỷ lệ mắc bệnh động mạch vành, với kiểu gen TT làm giảm nguy cơ mắc và được xem như một marker di truyền với bệnh này, đặc biệt ở nam giới hút thuốc lá [14]. Bên cạnh đó, đột biến ở gen $A T M$ còn ảnh hưởng đến nhiều tình trạng bệnh lý khác. Gen $A T M$ có vai trò trong các hoạt động như sửa chữa DNA, điều hòa chu kỳ tế bào, miễn dịch, chuyển hóa, sinh sản và tuổi thọ con người [15]. Mặc dù chưa có phương pháp điều trị chắc chắn trong thời điểm hiện tại, nhưng liệu pháp gen sẽ là một hướng tiếp cận đầy tiềm năng trong tương lai, với nhiều nghiên cứu trên mô hình đang được thực hiện trong thời gian gần đây. Các nghiên cứu về đột biến gen $A T M$ nói chung và đa hình di truyền rs11212617 nói riêng là một trong những bước đi khám phá về hoạt động chức năng cũng như liên kết của gen $A T M$, góp phần thúc đẩy cho những tiến bộ về liệu pháp gen tiến gần hơn nữa với ứng dụng điều trị thực tiễn.

\section{Kết luận}

Chúng tôi đã xây dựng được quy trình phân tích SNP rs11212617 trên mẫu máu và áp dụng thành công quy trình này phân tích gen trên 22 bệnh nhân ĐTĐ type 2 . Kết quả này sẽ giúp phát triển các nghiên cứu tiếp theo về $\mathrm{SNP}$ rs11212617 cũng như đột biến gen $A T M$, phục vụ cho các ứng dụng trong điều trị lâm sàng.

\section{Lời cảm ơn}

Chúng tôi trân trọng cảm ơn sự tài trợ của Đại học Quốc gia Hà Nội cho đề tài mã số CS. 17.05 và sự giúp đỡ của bác sĩ khoa Nội, Bệnh viện Dệt May để thực hiện nghiên cứu này.

\section{Tài liệu tham khảo}

[1] World Health Organization, Global report on Diabetes. 2016: Geneva.

[2] Bộ Y Tế (2015), Báo cáo tổng quan chung ngành Y tế năm 2014. Tăng cường dự phòng và kiểm soát bệnh không lây nhiễm, NXB Y học pp.138-175.

[3] D.L. Kasper, S.L. Hause, A.S. Fauci, D.L. Longo, J.L. Jameson, and J. Loscaizo (2012), "Diabetes Mellitus: Diagnosis, classification and pathophysiology", in Harrison's Principles of 
Internal Medicine 19th Edition, D.L. Kasper, S.L. Hause, A.S. Fauci, D.L. Longo, J.L. Jameson, and J. Loscaizo, Editors, McGraw Hill Education, pp. 2399-2407.

[4] American Diabetes Association (2017), "Standards of medical care in diabetes - 2017", Diabetes Care, 40 (Suppl 1).

[5] S.F. University of California. Gene variant explains differences in diabetes drug response. ScienceDaily 2016 [cited 21/10/2017]; Available from: https:/www.sciencedaily.com/releases/2016/08/160 816134151.htm.

[6] N. Van Leeuwen, G. Nijpels, M.L. Becker, H. Deshmukh, K. Zhou, et al. (2012), "A gene variant near ATM is significantly associated with metformin treatment response in type 2 diabetes: a replication and meta-analysis of five cohorts", Diabetologia, 55(7), pp. 1971-1977.

[7] K. Zhou, C. Bellenguez, C.C. Spencer, A.J. Bennett, R.L. Coleman, et al. (2011), "Common variants near ATM are associated with glycemic response to metformin in type 2 diabetes", Nature genetics, 43(2), pp. 117-120.

[8] F. Shokri, H. Ghaedi, S. Ghafouri Fard, A. Movafagh, S. Abediankenari, A. Mahrooz, Z. Kashi, and M.D. Omrani (2016), "Impact of ATM and SLC22A1 Polymorphisms on Therapeutic Response to Metformin in Iranian Diabetic Patients", International Journal of Molecular and Cellular Medicine, 5(1), pp. 1-7.

[9] J.C. Florez, K.A. Jablonski, A. Taylor, K. Mather, E. Horton, N.H. White, E. Barrett-Connor, W.C.
Knowler, A.R. Shuldiner, T.I. Pollin, and D.P.P.R. Group (2012), "The C allele of ATM rs11212617 does not associate with metformin response in the Diabetes Prevention Program", Diabetes Care, 35(9), pp. 1864-1867.

[10] Y. Zhou, Y. Guo, W. Ye, Y. Wang, X. Li, Y. Tian, Z. Liu, S. Li, and J. Yan (2014), "RS11212617 is associated with metformin treatment response in type 2 diabetes in Shanghai local Chinese population", International Journal of Clinical Practice, 68(12), pp. 1462-1466.

[11] Bộ Y Tế (2017), Hướng dẫn chẩn đoán và điều trị đái tháo đường týp 2, NXB Y học pp.1-17.

[12] Y. Espach, A. Lochner, H. Strijdom, and B. Huisamen (2015), "ATM protein kinase signaling, type 2 diabetes and cardiovascular disease", Cardiovascular Drugs and Therapy, 29(1), pp. 51-58.

[13] S. Schiekofer, I. Bobak, M.E. Kleber, W. Maerz, G. Rudofsky, K.A. Dugi, and J.G. Schneider (2014), "Association between a gene variant near ataxia telangiectasia mutated and coronary artery disease in men", Diabetes and Vascular Disease Research, 11(1), pp. 60-63.

[14] X. Ding, Y. He, Q. Hao, S. Chen, M. Yang, S.X. Leng, J. Yue, and B. Dong (2018), "The association of single nucleotide polymorphism rs $189037 \mathrm{C}>\mathrm{T}$ in ATM gene with coronary artery disease in Chinese Han populations", Medicine, 97(4).

[15] M.W. Chaudhary and R.S. Al-Baradie (2014), "Ataxia-telangiectasia: future prospects", The Application of Clinical Genetics, 7, pp. 159-167.

\title{
Establishing the Protocol for Detecting rs11212617 Polymorphism Related to Metformin Response in Type 2 Diabetic Patients
}

\author{
Nguyen Thi Thuy Mau ${ }^{1}$, Pham Thi Hong Nhung ${ }^{1}$, Do Thi Le Hang ${ }^{1}$, \\ Phi Thi Tu Anh ${ }^{1}$, Vu Thi Thom ${ }^{1}$, Pham Thi Quan ${ }^{2}$ \\ ${ }^{1}$ VNU School of Medicine and Pharmacy, 144 Xuan Thuy, Cau Giay, Hanoi, Vietnam \\ ${ }^{2}$ Hanoi Medical University, 1 Ton That Tung, Dong Da, Hanoi, Vietnam
}

\begin{abstract}
Metformin is currently recommended as a first-line drug for treatment of hyperglycemia in patients with type 2 diabetes. Nevertheless, the drug's treatment effect is not uniform in all patients. The recent studies have indicated that the single-nucleotide polymorphism (SNP) rs11212617 (C>A) (11q22.3), located near the ataxia telangiectasia mutated (ATM) gene, is
\end{abstract}


associated with Metformin treatment response, in which, allele $\mathrm{C}$ is better than allele A. Therefore, an SNP detecting protocol for a group of Vietnamese type 2 diabetic patients was to be established. The DNA, PCR and sequencing-extracted blood samples were applied to identify rs 11212617 polymorphism among 22 Vietnamese patients. Out of the 22 patients genotyped for rs 11212617 polymorphism, $\mathrm{CC}$ and $\mathrm{AA}$ were the homozygous genotypes with frequency of $54.5 \%$ and $13.7 \%$, respectively. $31.8 \%$ of the patients had heterozygous genotype $\mathrm{CA}$. The frequencies of allele $\mathrm{C}$ and allele A were 0.71 and 0.29 , respectively. This result is expected to help develop further studies aimed to evaluate the association between genetic polymorphism with clinically drug response in Vietnamese population and thereby, improving the effectiveness of treatment.

Keywords: Single nucleotide polymorphism, rs11212617, ATM gene, metformin, type 2 diabetes. 